\title{
A Touching Connection
}

\author{
Citation for published version (APA):
}

Huijnen, C. A. G. J. (2018). A Touching Connection: Robot mediated interventions for children with autism spectrum disorder. [Doctoral Thesis, Maastricht University]. Maastricht University. https://doi.org/10.26481/dis.20181212ch

Document status and date:

Published: 01/01/2018

DOI:

10.26481/dis.20181212ch

Document Version:

Publisher's PDF, also known as Version of record

\section{Please check the document version of this publication:}

- A submitted manuscript is the version of the article upon submission and before peer-review. There can be important differences between the submitted version and the official published version of record.

People interested in the research are advised to contact the author for the final version of the publication, or visit the DOI to the publisher's website.

- The final author version and the galley proof are versions of the publication after peer review.

- The final published version features the final layout of the paper including the volume, issue and page numbers.

Link to publication

\footnotetext{
General rights rights.

- You may freely distribute the URL identifying the publication in the public portal. please follow below link for the End User Agreement:

www.umlib.nl/taverne-license

Take down policy

If you believe that this document breaches copyright please contact us at:

repository@maastrichtuniversity.nl

providing details and we will investigate your claim.
}

Copyright and moral rights for the publications made accessible in the public portal are retained by the authors and/or other copyright owners and it is a condition of accessing publications that users recognise and abide by the legal requirements associated with these

- Users may download and print one copy of any publication from the public portal for the purpose of private study or research.

- You may not further distribute the material or use it for any profit-making activity or commercial gain

If the publication is distributed under the terms of Article $25 \mathrm{fa}$ of the Dutch Copyright Act, indicated by the "Taverne" license above, 
Valorisation

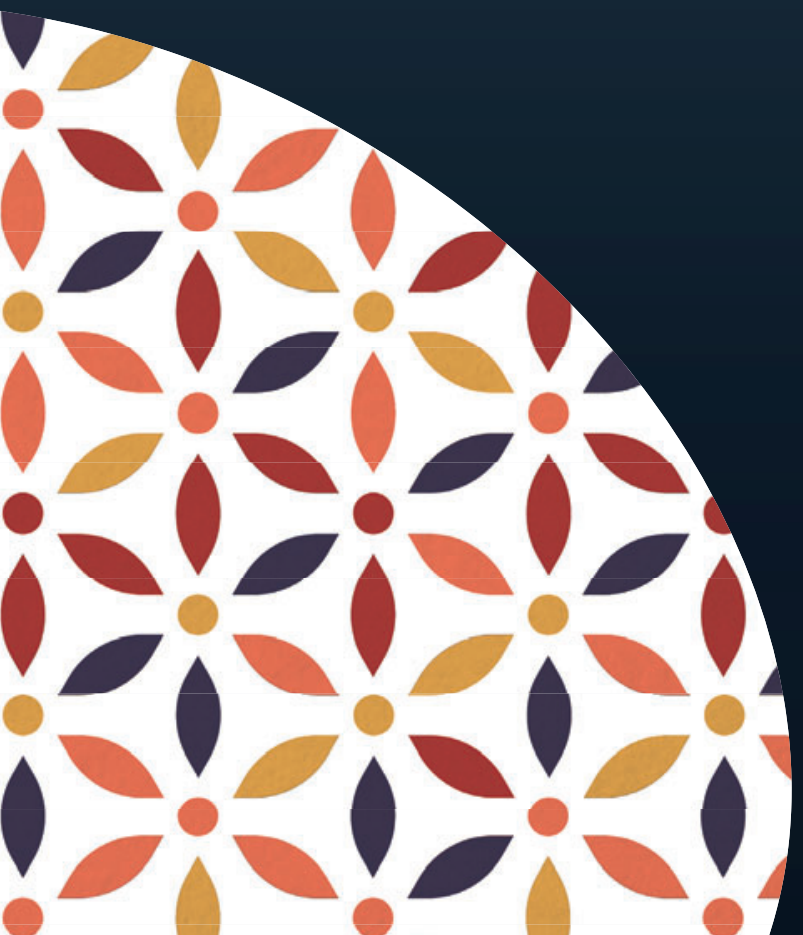




\section{Valorisation}

The research described in this dissertation was part of a larger research project called 'Social robots in care'. It was funded by the RAAK-PRO program of 'Stichting Innovatie Alliantie' of the Dutch Ministry of Education, Culture and Science (project number RAAK PRO-4-10). It focused on the practical application of three robot platforms (ZORA, PARO and KASPAR) for three target groups (children with physical disabilities, older people with dementia and children with autism spectrum disorder respectively). This thesis is part of the subproject studying interventions using KASPAR for children with autism. The studies conducted in this dissertation describe the potential and practical application of robot-mediated interventions (RMI) in practices for children with autism spectrum disorder (ASD), in particular robot KASPAR.

The use of robots is considered a promising direction to augment education or therapy practices for children with autism. However, to date, not much is known (in literature nor practice) about hów to integrate robots in educational and therapeutic protocols and settings. Successful integration of robots in school settings requires teachers' acceptance and adoption. Therefore we intensively involved professionals and other stakeholders throughout the research. For the outcomes of the research to be of real value, publishing in scientific peer reviewed journals is not sufficient to reach all relevant stakeholders. Besides the scientific community, also daily practice, educational settings and the general public may benefit from the lessons learned. This valorisation chapter describes the impact of the research findings on education, practice and society.

Valorisation can be seen as the process of value creation from knowledge, by making knowledge available or suitable for societal use and to make it appropriate for translation into products, services, processes and new commercial activities. In this project no commercial products or services have been delivered. We used a robot that was and is in prototype stage and contributed to the improvement of that prototype (new KASPAR scenarios have been developed, new requirements were elicited and practical insights were delivered). The valorisation of the results has largely been done throughout the conduction of and communication about the research itself. The intensive involvement of different target groups and numerous dissemination activities for various audiences created valuable insights on the application of robot-mediated interventions for different populations, which will be described in more detail. These populations are the general public, professionals and other stakeholders working in practice with children with autism, children with autism, students from different educations, and researchers and robot developers. 


\section{General public}

For the general public this project contributed to the awareness and discussion on the use of robots in care or education. This was done by opening up the dialogue on this topic and sharing insights gathered so far. A number of concrete results and activities have been delivered. An accessible book is published and shared on the application of social robots in care: "Sociale robots in de zorg: van experiment tot zorgpraktijk" (ISBN 978-90-77901-90-8). A number of dissemination activities targeted at the general public have been undertaken, for example: contribution to the Futurum event, Rabobank member's only event, demonstration and presentation for the "Zorginnovatiewinkel" by the Ministery of Health, Sport and Science, KASPAR was included in a book on old and new technology created by the CUBE museum, Parcours of Arts and Science (PAS) event by the University of Maastricht, demonstrations and presentation at the "Showroom van nu" and "Lunchen met robots" by the Ministry of Health, Sports and Science in The Hague and many more. The project also received quite some media attention. We were invited and interviewed four times by L1; twice for their TV programme Avondgasten and for radio and television news. Also we participated in a number of other television programmes of RTL 4 and RTL 5. A short movie was made for Heerlen Smart City Smart Services. Moreover, a 2Doc documentary for NPO2 was made by director Sander Burger called "Scenario's voor een normaal leven" (Scenarios for a normal life). The goal of the documentary was to raise (public) awareness about autism and a potential role for a robot for children with autism. A boy called Jonathan is the main character in the documentary. Recordings were made of him at school, at home and during sessions with KASPAR. The documentary was broadcasted on national Dutch television, shown in the cinema "Filmhuis de Domijnen" for three (sold out) days, and can still be viewed online (also a version with English subtitles is available from the producers "Hollandse Helden"). The documentary received a lot of attention in the media and reached many people in the general public in the Netherlands. Interviews were given for local radio/television news channels (L1, OmroepStart Geleen). National and local newspapers and TV guides published about it (e.g. Trouw, De Volkskrant, NRC, De Limburger, VPRO gids). Also we were invited for the live TV program "Tijd voor Max" at prime time, with 1 million viewers (the day before the documentary was broadcasted). Articles have been written for/by the University of Maastricht, Hallo Limburg, Brigthlands, Zuyd Hogeschool. Radio interviews were given for "Omroep Start Geleen", L1 and the VPRO guide. The documentary and the media attention that was generated afterwards resulted in quite some interest from parents of children with autism and professionals working in practice. Also, from people in our network we heard that parents of children with autism started to communicate in a KASPAR kind of way with their children and it delivered positive results. We heard often that viewing KASPAR at work with Jonathan, made people more aware of their own behaviour and they tried to be more "neutral" 
in the interactions with their children with autism. We are approached by several events, organisations, parents and professionals of children with autism with the question if we are willing to think about continuing this work.

\section{Professionals and other stakeholders working with children with autism}

The studies conducted demonstrate that there is potential in the use of robots for children with autism and that professionals are keen on and motivated for co-creating new robot-mediated interventions. Practical knowledge was gathered on how to create and apply robots in real life settings for children with autism. This is a new field of knowledge. Our approach was innovative in the sense that a large number professionals from many organisations were involved in an intensive manner. All these professionals have contributed without any kind of financial incentive. Professionals and other stakeholders (parents of children with autism, children and adults with autism, children with autism, and partners of people with autism) collaborated in focus group sessions and co-creation sessions. Often it was mentioned by participants that talking about their work and sharing experiences with peers gave them more insights and reflection about their own work. Together they were constructing the new upcoming field of robot-mediated interventions. Many of them expressed that they highly valued this involvement. Often people introduced the researchers to their colleagues at other organisations, stimulating their peers to participate in the research too. Besides the participation and voice that professionals and other stakeholders had in the research, also about hundred presentations, demonstrations and workshops have been given at special schools, (health)care organisations, (autism) interest organisations, and government bodies in this area. Some examples are presentations/demonstrations/workshops for organisations such as Meander, Adelante, Radar, Koraalgroep, Dutch Association for Autism (Nederlandse Vereniging voor Autisme), Vivium, De Parkschool, Stichting Mee, and Horizon. Also activities for national and local government bodies have been organised such as the Dutch Ministry of Health, Welfare and Sport, the Province of Limburg, and management of the municipality Parkstad Limburg).

\section{Children with autism}

Children with autism are considered as a 'population' that would hopefully benefit in the future from interactions with robots at school, in therapy settings or maybe even at home. Jonathan (the boy from the documentary) and (most of) the children who participated in the effect study visibly opened up and enjoyed the KASPAR sessions. Some of them also asked for KASPAR later on or called KASPAR their friend. Moreover, next to this element of fun, also positive effects were seen in their behaviour with 
respect to making contact and attention. Other studies report similar positive outcomes about the effects of robots for children with autism.

\section{Education}

The insights and knowledge gathered through this research are incorporated in various teaching activities of students from different disciplines and new educational content has been developed. Presentations, demonstrations, lectures, workshops have been given to students in the fields of occupational therapy, speech therapy, ICT, (healthcare) engineering, iArts, communication and multimedia design, psychology, advanced nursing, engineering students and even to primary school pupils. Multiple (applied) Universities have been involved: Maastricht University, Tilburg University, Delft University, Technical University of The Hague, Technical University of Eindhoven, Applied University of Windesheim, Applied and Technical Universities of Aachen (Germany), Applied University of Hasselt (Belgium), Jazan Applied University (Saoudi Arabia), Tokyo Metropolitan University (Japan), Linköping University (Sweden), ZorgTechniek Limburg, and German occupational therapy faculty. A number of students have participated thoroughly in the project which resulted in four theses. Two psychology students from Maastricht University contributed, a philosophy student from Tilburg University, a group of three occupational therapy students from Zuyd University of Applied Sciences, and a communication and multimedia Design student from Zuyd University of Applied Sciences.

\section{Researchers and robot developers}

For researchers and robot developers the practical insights on RMI gained from the professionals and other stakeholders are of value. For example:

- the objectives overview that shows important goals for children with autism;

- $\quad$ possible roles for robots;

- practical requirements;

- the intervention template that guides RMI developers when creating new robotmediated interventions;

- the development of a number of co-created KASPAR scenarios.

Four articles addressing these findings have been published in international peer reviewed journals and an additional fifth article is under review. Also a short commentary is published in the International Journal of Neurorehabilitation. The work with KASPAR was also communicated in and with help of the LUDI network. This is a network enabling exchange of knowledge and experience. Specifically the aim is to promote international exchange of knowledge and expertise in the area of supporting play for children with disabilities. LUDI supported a Short Term Scientific Mission (STSM) exchange visit to the University of Hertfordshire. Findings and experiences on 
working with KASPAR for children with autism were shared during this exchange visit. Various presentations and demonstrations have been given at conferences and other events and several articles have been written for non-scientific readers.

\section{Current status and outlook}

The KASPAR robot that was used in the studies in this dissertation is a prototype developed by the University of Hertfordshire in the UK. It is not yet commercially available, however commercialisation plans and actions are being put in place at the moment. It is the aim to have KASPAR available on the market in the next few years.

Although this thesis did not deliver new products or services, it can be said that new insight were created on the potential of robot-mediated interventions for children with autism. A large share of these insights are not KASPAR specific and apply also when working with other robot platforms for children with autism. Currently, still regular requests are being made for presentations, demonstrations or new research activities. As a conclusion, it seems worthwhile to continue efforts investigating and co-creating this area towards practical implementation in current practices. 